\title{
Entropic Heat Effects in Aluminum Electrolysis Cells with Inert Anodes
}

\begin{abstract}
ASBJØRN SOLHEIM
While the overall energy requirement for the aluminum electrolysis is well known and can be calculated from readily available thermodynamic data, the distribution of the different types of energy to the anode, the cathode, and the electrolyte is not straightforward. The present attempt is based on the application of activity data including partial entropies on the electrode reactions in a cell operating with inert anodes. The calculations indicate that the cell reaction implies a relatively strong cooling of the anode, a moderate heating of the cathode, and a moderate cooling of the electrolyte. The mass- and heat transfer coefficients at the anode in a cell with inert anodes were estimated. The electrolyte at the anode will be higher in aluminum fluoride, lower in alumina, and colder than the bulk of the electrolyte. The cooling and heating effects are only marginally different from the situation prevailing in traditional aluminum electrolysis cells with carbon anodes.
\end{abstract}

DOI: $10.1007 / \mathrm{s} 11663-015-0561-1$

(C) The Minerals, Metals \& Materials Society and ASM International 2016

\section{INTRODUCTION}

AlL major aluminum companies apply elaborate mathematical models for cell design, cell control, and operation. Due to the need of protecting the cell lining by a layer of frozen electrolyte (side ledge), it is very important to control the overall energy balance of the cell. Therefore, the heat losses from the cell are being mapped in detail by computation as well as by measurements. In the author's opinion, the electrolysis process is generally well understood, and, in particular, the distribution of heat losses. However, the fundamental understanding is scarce when it comes to non-ohmic heat sources. Even in advanced mathematical models used by the industry, the internal heat sources and sinks are not separated into different terms and distributed to their correct locations in the cell.

The overall entropic heat effect in the cell reaction can easily be calculated from thermodynamic data, e.g., JANAF. ${ }^{[1]}$ However, the distribution of the heat to the anode, the cathode, and the electrolyte is not trivial. It has been shown by several authors that the entropy associated with the cell reaction leads to relatively strong cooling of the anode in traditional aluminum electrolysis cells with carbon anodes. ${ }^{[2-9]}$ Several methods have been used for the assessment of the cooling intensity. Mozhaev et al. ${ }^{[2,3]}$ were probably the first to describe heat effects on individual electrodes in aluminum electrolysis cells. Their work was based on direct temperature measurements, ${ }^{[2]}$ and the findings were later confirmed by the measured Seebeck coefficient. ${ }^{[3]}$ Ratkje $^{[4]}$ distributed the total entropy to the individual electrodes by using irreversible thermodynamics.

ASBJØRN SOLHEIM, Chief Scientist, is with SINTEF Materials and Chemistry, P.O. Box 4760 Sluppen, NO-7465 Trondheim, Norway. Contact e-mail: asbjorn.solheim@sintef.no

Manuscript submitted August 17, 2015.

Article published online January 5, 2016.
Ødegård et al. ${ }^{[5,6]}$ based their treatment on estimated thermodynamic data for the anion species assumed to be present, whereas Flem et al. ${ }^{[7]}$ derived the entropic heat effects from experimentally determined Seebeck coefficients. The work by Kjelstrup et al. ${ }^{[8]}$ was based on measuring temperature changes at the electrodes, following steps in the electrolysis current. Solheim's treatment ${ }^{[9]}$ was based on the same principle as used by Ødegård et al. ${ }^{[6]}$ but formal activity data for $\mathrm{NaF}, \mathrm{AlF}_{3}$, and $\mathrm{Al}_{2} \mathrm{O}_{3}$ derived by Solheim and Sterten ${ }^{[10]}$ were used instead of estimated thermodynamic data for the anions present.

So far, there have been no attempts to assess the entropic heat effects in cells with inert anodes, although all methods mentioned above can be applied. The present work can be regarded as a direct continuation of recent work concerning a cell with carbon anodes, ${ }^{[9]}$ inasmuch as the same method was applied.

\section{CELL REACTION: OVERALL THERMODYNAMIC DATA}

The cell reaction in aluminum electrolysis with inert anodes is simply

$$
\frac{1}{2} \mathrm{Al}_{2} \mathrm{O}_{3}(\alpha, s) \stackrel{3 F}{=} \mathrm{Al}(1)+\frac{3}{4} \mathrm{O}_{2}(g)
$$

The energy changes related to any reaction can be divided into three terms; $\Delta G^{0}$ (standard necessary work for realizing the reaction at reversible conditions), $\Delta H^{0}$ (standard total energy required for the reaction to proceed at adiabatic and isothermal conditions), and $T \Delta S^{0}$ (heat due to change in standard entropy). The terms are related by

$$
\begin{aligned}
\Delta H^{0} & =\Delta G^{0}+T \cdot \Delta S^{0} \\
845,500 & =642,178+1233 \cdot 164.90 \quad \mathrm{~J} \mathrm{~mol}^{-1},
\end{aligned}
$$


where the thermodynamic data for Reaction [1] at $1233 \mathrm{~K}$ $\left(960{ }^{\circ} \mathrm{C}\right)$ was found by interpolation in the JANAF tables ${ }^{[1]}$

All terms in Eq. [2] were divided by $-3 F$ where $F$ is Faraday's constant $\left[96,485 \mathrm{As} \mathrm{mol}^{-1}\right]$, to obtain

$$
\begin{aligned}
E^{\text {iso }} & =E^{0}+\frac{T \cdot \Delta S^{0}}{3 F} \\
-2.921 & =-2.219-0.702 \mathrm{~V},
\end{aligned}
$$

where $E^{\text {iso }}$ is the isothermal cell voltage and $E^{0}$ is the standard cell voltage (both are formally negative). The standard cell voltage is the voltage necessary for starting the cell reaction with all reactants and product in their standard state, while the isothermal voltage is the voltage necessary for sustained electrolysis in adiabatic and isothermal conditions. If the electrolysis was to be continued with applied voltage lower than $2.921 \mathrm{~V}$ even in a perfectly insulated cell, the temperature would decrease with time. This means that the entropy term corresponding to $-0.702 \mathrm{~V}$ in fact represents cooling of the cell. The total cooling effect can be calculated by

$$
Q=-0.702 \cdot I[\mathrm{~W}]
$$

where $I$ is the amperage, e.g., $Q=-211 \mathrm{~kW}$ in a $300 \mathrm{kA}$ cell.

It is not so easy to explain what entropy really "is." According to the second law of thermodynamics, the entropy of an isolated system never decreases, and the term is commonly regarded as a measure of disorder. Increase of volume generally increases disorder, and reactions with gas evolution always show a strong increase in the entropy. The data in Eq. [3] represent only the total cooling, i.e., the sum of the entropy effect at the anode, in the electrolyte, and at the cathode. Still, from the fact that gas evolution takes place at the anode, one may expect $a$ priori that the largest cooling term is located there.

The minimum energy needed for the cell reaction must also take into account the heating of alumina, as shown in Table I. As can be observed, however, the energy required in the cell reaction itself dominates totally.

\section{ELECTRODE REACTIONS}

The electrode reactions are the natural starting points for distribution of the overall entropy to the electrodes and the electrolyte. The cathode and anode reactions, respectively, can be written

$$
3 \mathrm{Na}^{+}+3 e^{-}+\mathrm{AlF}_{3}(s) \stackrel{3 F}{\rightarrow} \mathrm{Al}(\mathrm{l})+3 \mathrm{NaF}(l)
$$

$$
\begin{gathered}
\frac{1}{2} \mathrm{Al}_{2} \mathrm{O}_{3}(\alpha, s)+3 \mathrm{NaF}(l) \stackrel{3 F}{\rightarrow} \frac{3}{4} \mathrm{O}_{2}(g) \\
+\mathrm{AlF}_{3}(s)+3 \mathrm{Na}^{+}+3 e^{-} .
\end{gathered}
$$

With data taken from $\mathrm{JANAF}^{[1]}$, the changes in standard entropy at $1233 \mathrm{~K}\left(960^{\circ} \mathrm{C}\right)$ become

For the cathode reaction: $\Delta S_{c}^{0}$

$$
=350.05-3 S_{\mathrm{Na}^{+}}^{0}-3 S_{e}^{0}\left[\mathrm{JK}^{-1} \mathrm{~mol}^{-1}\right]
$$

$$
\begin{aligned}
& \text { For the anode reaction: } \Delta S_{a}^{0} \\
& \quad=-175.15+3 S_{\mathrm{Na}^{+}}^{0}+3 S_{e}^{0}\left[\mathrm{JK}^{-1} \mathrm{~mol}^{-1}\right]
\end{aligned}
$$

The sum of these entropy changes becomes $164.90 \mathrm{JK}^{-1} \mathrm{~mol}^{-1}$, as for the main reaction [1].

Equations [7] and [8] illustrate the two main challenges in distributing the entropy change to the different locations; (i) the entropies for ions and the electron are generally not known, and (ii) only standard entropy data are readily available, while the substances taking part in the electrode reactions are not in their standard states (except oxygen and aluminum).

\section{DISTRIBUTION OF ENTROPY}

\section{A. Entropy for Electrons and the Sodium Ion}

For the reaction

$$
\mathrm{Na}^{+}+e=\mathrm{Na}(l)
$$

the change in entropy must be assumed to be small. This is because the entropy for electrons is small, and there are no large volume changes (only condensed phases). The assumption is also supported by measurements in molten sodium hydroxide. ${ }^{[1]}$ Therefore, we can apply the approximation

$$
S_{\mathrm{Na}^{+}}^{0}+S_{\mathrm{e}}^{0} \approx S_{\mathrm{Na}(l)}^{0}=100.74 \mathrm{JK}^{-1} \mathrm{~mol}^{-1}
$$

which is the same approximation as suggested by Ødegård et al. ${ }^{[5,6]}$ By inserting this result into Eqs. [7] and [8], the standard change of entropy in the electrode reactions becomes:

$$
\Delta S_{\mathrm{c}}^{0}=37.83 \mathrm{JK}^{-1} \mathrm{~mol}^{-1}
$$

Table I. Minimum Energy Required in the Cell Reaction, Calculated with Data from JANAF ${ }^{[1]}$

\begin{tabular}{lrr}
\hline & $\mathrm{J} \mathrm{mol}^{-1}$ & $\mathrm{~V}$ \\
\hline Heating of $\gamma-\mathrm{Al}_{2} \mathrm{O}_{3}, 298 \mathrm{~K}$ to $1233 \mathrm{~K}\left(25^{\circ} \mathrm{C}\right.$ to $\left.960{ }^{\circ} \mathrm{C}\right)$ & 112,591 & 0.389 \\
$\gamma-\mathrm{Al}_{2} \mathrm{O}_{3}$ to $\alpha-\mathrm{Al}_{2} \mathrm{O}_{3}$ at $1233 \mathrm{~K}\left(960{ }^{\circ} \mathrm{C}\right)$ & $-23,882$ & -0.083 \\
Reaction at $1233 \mathrm{~K}\left(960{ }^{\circ} \mathrm{C}\right)$ & 845,500 & 2.921 \\
Sum & 934,209 & 3.227 \\
\hline It is assumed that the feed consists of $\gamma$-alumina, while the cell reaction starts with $\alpha$-alumina. & 9.705 \\
\hline
\end{tabular}




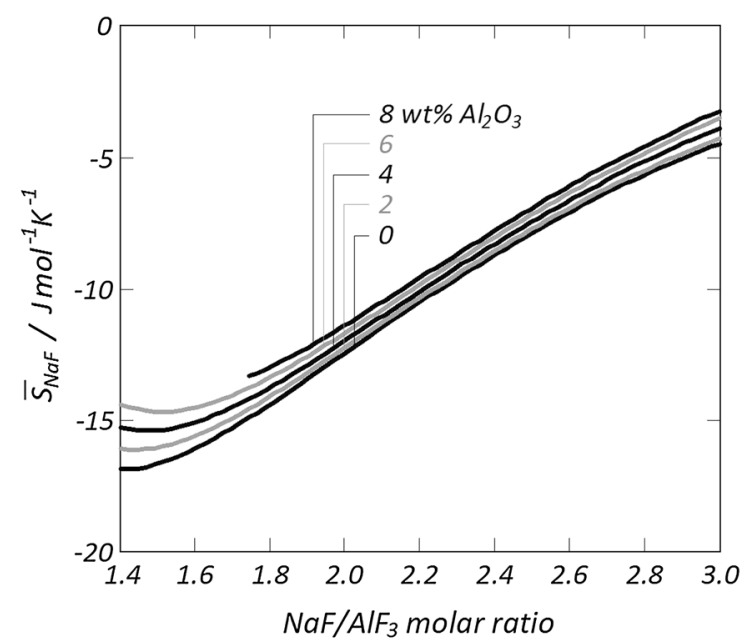

(a)

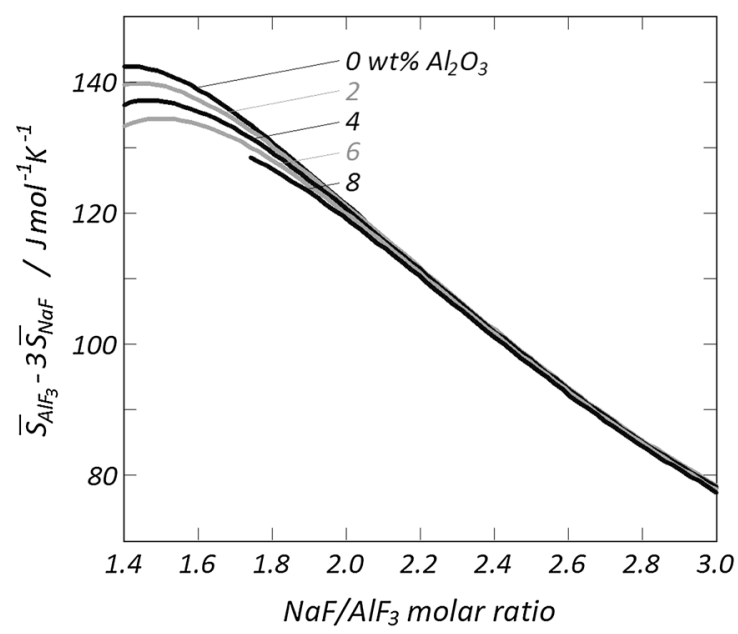

(c)

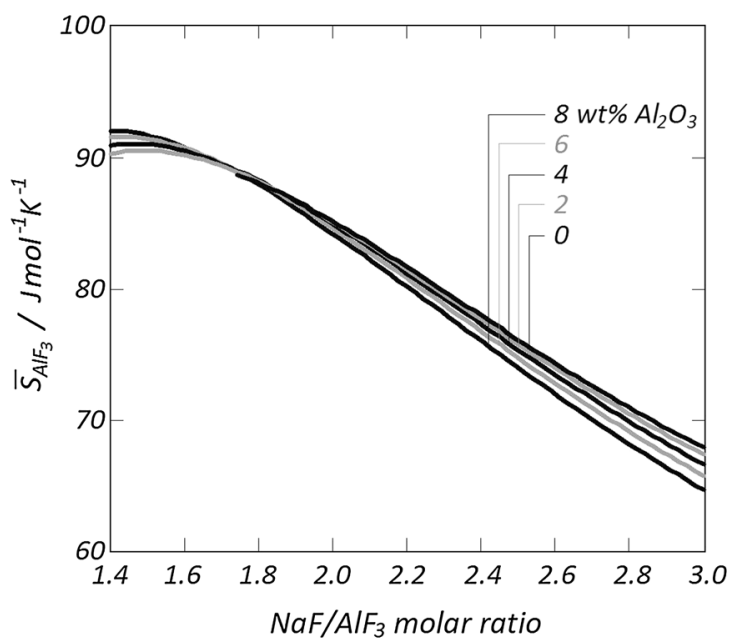

(b)

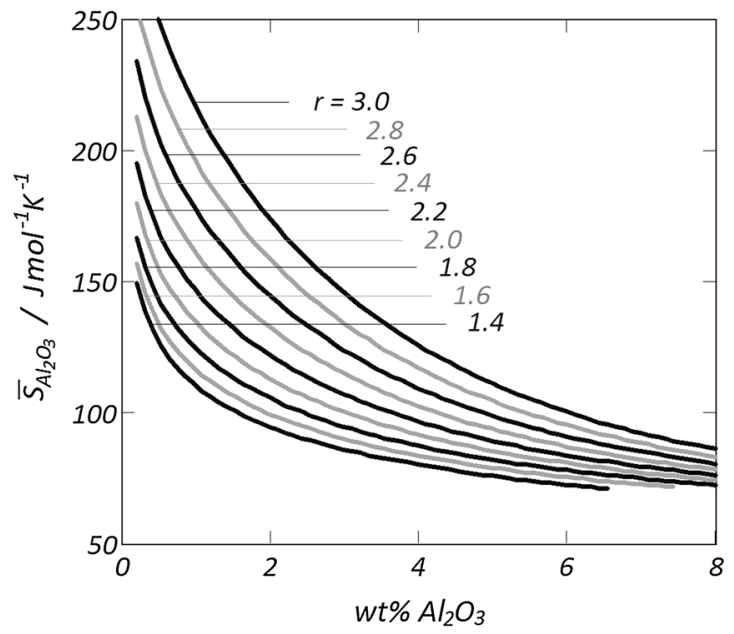

(d)

Fig. 1-Partial entropies of mixing calculated from equations given by Solheim and Sterten ${ }^{[10]}(a)$ for sodium fluoride as a function of the NaF/ $\mathrm{AlF}_{3}$ molar ratio $(r),(b)$ for aluminum fluoride as a function of $r,(c)$ for $\left(\mathrm{AlF}_{3}-3 \mathrm{NaF}\right)$ as a function of $r,(d)$ for alumina as a function of the alumina concentration at different $r$.

$$
\Delta S_{\mathrm{a}}^{0}=127.07 \mathrm{JK}^{-1} \mathrm{~mol}^{-1}
$$

\section{B. Partial Molar Entropies}

As was mentioned above, the substances taking part in the electrode reactions are generally not in their standard states. For any substance $i$, the total entropy is the sum of its standard entropy of formation and its partial entropy of mixing:

$$
S_{i}=S_{i}^{0}+\overline{S_{i}} \text { where } \overline{S_{i}}=\frac{\overline{H_{i}}}{T}-R \ln a_{i} .
$$

Here, $R$ is the universal gas constant [8.3143 $\left.\mathrm{J} \mathrm{mol}^{-1} \mathrm{~K}^{-1}\right], \bar{H}$ is the partial heat of mixing, and $\mathrm{a}$ is the activity. Thus, the entropy change in the cathode Reaction [5] becomes

$$
\Delta S_{\mathrm{c}}=37.83+3 \bar{S}_{\mathrm{NaF}}-\bar{S}_{\mathrm{AlF}_{3}}\left[\mathrm{Jmol}^{-1} \mathrm{~K}^{-1}\right] .
$$

For the anode Reaction [6],

$$
\Delta S_{\mathrm{a}}=127.07-3 \bar{S}_{\mathrm{NaF}}+\bar{S}_{\mathrm{AlF}_{3}}-\frac{1}{2} \bar{S}_{\mathrm{Al}_{2} \mathrm{O}_{3}}\left[\mathrm{Jmol}^{-1} \mathrm{~K}^{-1}\right] .
$$

and for dissolution of alumina

$$
\Delta S_{\mathrm{diss}}=\frac{1}{2} \bar{S}_{\mathrm{Al}_{2} \mathrm{O}_{3}}\left[\mathrm{Jmol}^{-1} \mathrm{~K}^{-1}\right] .
$$

The partial entropies for sodium fluoride, aluminum fluoride, and alumina were calculated from the activity data derived by Solheim and Sterten. ${ }^{[10]}$ In that work the activities, including total and partial heats of mixing, were expressed analytically. The relevant partial entropies of mixing are shown graphically in Figure 1.

The activity model by Solheim and Sterten ${ }^{[10]}$ was originally intended as an amendment to the earlier model by Sterten et al. ${ }^{[12]}$ in order to achieve better agreement with experimental liquidus temperature data. Dewing ${ }^{[13]}$ derived activity data for the system $\mathrm{NaF}-\mathrm{AlF}_{3}$, but the results were given on tabular form rather than as analytical expressions. For the system 
$\mathrm{Na}_{3} \mathrm{AlF}_{6}-\mathrm{Al}_{2} \mathrm{O}_{3}$, there is very good agreement between Solheim and Sterten ${ }^{[10]}$ and Dewing and Thonstad. ${ }^{[14]}$ Generally, the mentioned activity models show the same trends, and all models are based on Hong and Kleppa's set of experimental enthalpies of mixing in the system $\mathrm{NaF}-\mathrm{AlF}_{3} \cdot{ }^{[15]}$

\section{HEATING AND COOLING EFFECTS}

The entropies can be represented by a corresponding potential:

$$
E_{j}=-\frac{T \Delta S_{j}}{3 F}[\mathrm{~V}] .
$$

The corresponding heating becomes

$$
q_{j}=E_{j} \cdot i\left[\mathrm{Wm}^{-2}\right],
$$

where $i$ is the current density [A $\mathrm{m}^{-2}$ ]. In Eqs. [17] and [18], negative values represent cooling.

The entropy changes at the anode, the cathode, and the electrolyte were calculated by combining Eqs. [14] through [16] with the data shown in Figure 1, and the result is shown in Figure 2. As can be observed, there is

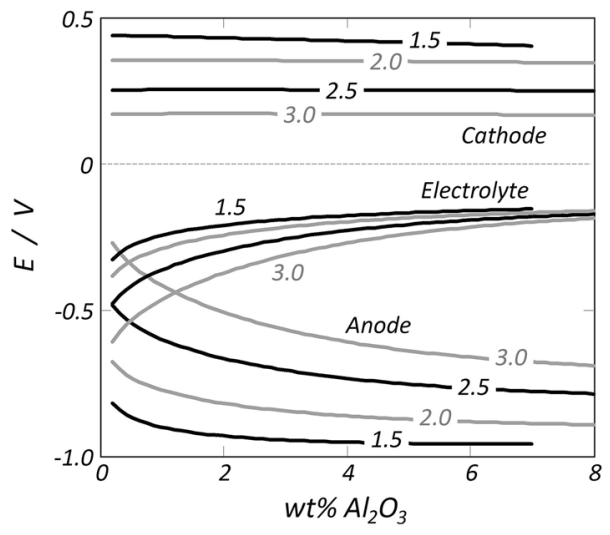

Fig. 2-Heat sources and sinks at the cathode, at the anode, and in the electrolyte, expressed as corresponding voltages (negative values represent cooling). The numbers in the figure represent the $\mathrm{NaF} /$ $\mathrm{AlF}_{3}$ molar ratio. a moderate heating of the cathode, about 0.2 to $0.4 \mathrm{~V}$ depending on the $\mathrm{NaF} / \mathrm{AlF}_{3}$ ratio, but almost independent of the alumina concentration. The cooling of the anode can be up to almost $1 \mathrm{~V}$, depending strongly on the alumina concentration as well as on the $\mathrm{NaF} / \mathrm{AlF}_{3}$ molar ratio.

The results from the present treatment are compared with some literature data concerning cells with carbon anodes in Table II. Generally, the difference between carbon anodes and inert anodes is very small. The cathode reaction is the same in the two cases, and the standard entropy change in the cell reaction is $164.90 \mathrm{Jmol}^{-1} \mathrm{~K}^{-1}$ with inert anodes and $165.52 \mathrm{Jmol}^{-1} \mathrm{~K}^{-1}$ with inert anodes. The difference represents less than $3 \mathrm{mV}$.

It appears that some of the earlier work failed in recognizing that the entropic heat related to dissolution of alumina is taken from the electrolyte. Mixing of alumina into the electrolyte is an endothermic process. However, the heat taken from the electrolyte becomes available again at the anode when the alumina is consumed, since electrolytic consumption of alumina can be regarded as the opposite of dissolution. As a result, the curves representing the anode and the electrolyte in Figure 2 are mirrored.

The work by Ødegård et al. ${ }^{[6]}$ represents the only indication of cooling at the cathode. The deviation between Ødegård et al. ${ }^{[6]}$ and Solheim ${ }^{[9]}$ appears mainly to be caused by different assessments of the entropies of mixing. It is probably correct that the cathode will be heated, as this was measured directly in laboratory cells by Mozhaev et al. ${ }^{[2]}$ as well as by Kjelstrup et al. ${ }^{[8]}$

The anodic overvoltage is approximately $0.5 \mathrm{~V}$ in cells with carbon anodes and much lower than that in cells with inert anodes, e.g., $0.1 \mathrm{~V}$ as was indicated by Kvande and Haupin. ${ }^{[16]}$ The heating due to the overvoltage is, therefore, far from sufficient to compensate the entropic cooling of the anode. Typically, the anode will be cooled corresponding to $-0.95 \mathrm{~V}$, since a cell with inert anodes must operate close to alumina saturation. The sum of entropic cooling $(-0.95 \mathrm{~V})$ and heating due to overvoltage $(0.1 \mathrm{~V})$ represents a large heat deficit, e.g., $8.5 \mathrm{~kW} \mathrm{~m}^{-2}$ at a current density of $10 \mathrm{kA} \mathrm{m}^{-2}\left(1 \mathrm{~A} \mathrm{~cm}^{-2}\right)$. The heat must be supplied by heat transfer from the electrolyte. This means that the anode will be colder than the surrounding electrolyte,

\begin{tabular}{|c|c|c|c|c|c|}
\hline & & Cathode & Anode & Electrolyte & Total \\
\hline \multirow[t]{5}{*}{ Carbon anodes } & Ratkje $^{[4]}$ & 0.18 & -0.90 & - & -0.72 \\
\hline & Ødegård et al..$^{[5]}$ & 0.16 & -0.89 & - & -0.73 \\
\hline & Ødegård et al..$^{[6]}$ & -0.07 & -0.60 & -0.06 & -0.73 \\
\hline & Flem et al. ${ }^{[6]}$ & 1.53 & -2.24 & - & -0.71 \\
\hline & Solheim ${ }^{[9]}$ & 0.31 & -0.78 & -0.24 & -0.71 \\
\hline \multirow[t]{4}{*}{ Inert anodes } & this work $\left(r=2.2,2.5 \mathrm{wt}\right.$ pct $\left.\mathrm{Al}_{2} \mathrm{O}_{3}\right)$ & 0.315 & -0.775 & -0.243 & -0.702 \\
\hline & this work $\left(r=1.5,2.5\right.$ wt pet $\left.\mathrm{Al}_{2} \mathrm{O}_{3}\right)$ & 0.430 & -0.940 & -0.193 & -0.702 \\
\hline & this work $\left(r=2.2,7.0 \mathrm{wt}\right.$ pct $\left.\mathrm{Al}_{2} \mathrm{O}_{3}\right)$ & 0.311 & -0.843 & -0.170 & -0.702 \\
\hline & this work $\left(r=1.5,7.0\right.$ wt pet $\left.\mathrm{Al}_{2} \mathrm{O}_{3}\right)$ & 0.406 & -0.956 & -0.152 & -0.702 \\
\hline
\end{tabular}

Table II. Voltages Related to Entropic Cooling and Heating at Different Locations in the Cell, According to Different Authors

The data by Ødegård et al. ${ }^{[5,6]}$ and Solheim ${ }^{[9]}$ are given for $\mathrm{NaF} / \mathrm{AlF}_{3}$ molar ratio $r=2.2,2.5$ wt pct alumina, and $T=1233 \mathrm{~K}\left(960{ }^{\circ} \mathrm{C}\right)$. 
even if the cell is arranged in such a way that there is no heat loss from the anode to the surroundings.

\section{ESTIMATE OF MASS- AND HEAT TRANSFER AT THE ANODE}

\section{A. Mass- and Heat Transfer Coefficients}

In a paper by Vogt and Stefan ${ }^{[17]}$, the mass transfer at gas evolving electrodes was treated comprehensively, including the effect of gas bubble coverage. The following equation was suggested:

$$
\begin{gathered}
\mathrm{Sh}=1.65 \cdot\left(\mathrm{Re}^{*} \cdot \mathrm{Sc}\right)^{0.5} \cdot \theta^{0.5}(1-\theta) \text { or } \\
k=1.65 \cdot \theta^{0.5}(1-\theta) \cdot\left(\frac{G D}{d}\right)^{0.5},
\end{gathered}
$$

where $\mathrm{Re}$ is the dimensionless Reynolds number for gas evolution, Sc is the dimensionless Schmidt number, $\theta$ is the gas bubble coverage, $k$ is the mass transfer coefficient $\left[\mathrm{m} \mathrm{s}^{-1}\right], G$ is the rate of gas evolution $\left[\mathrm{m}^{3} \mathrm{~s}^{-1} \mathrm{~m}^{-2}\right], D$ is the diffusion coefficient $\left[\mathrm{m}^{2} \mathrm{~s}^{-1}\right]$, and $d$ is the gas bubble diameter [m]. The diffusion coefficient for alumina in cryolite can be assumed to be $1.5 \times 10^{-9} \mathrm{~m}^{2} \mathrm{~s}^{-1}$, as suggested by Thonstad. ${ }^{[18]}$

Although Eq. [19] was derived for mass transfer, due to the analogy between mass transfer and heat transfer, it can be used for calculating heat transfer coefficients (h $\left[\mathrm{W} \mathrm{m}{ }^{-2} \mathrm{~K}^{-1}\right]$ ) by replacing $\mathrm{Sh}$ by the Nusselt number $\mathrm{Nu}$ ) and $\mathrm{Sc}$ by the Prandtl number $(\mathrm{Pr})$;

$$
\begin{gathered}
\mathrm{Nu}=1.65 \cdot\left(\mathrm{Re}^{*} \cdot \operatorname{Pr}\right)^{0.5} \cdot \theta^{0.5}(1-\theta) \text { or } \\
h=1.65 \cdot \theta^{0.5}(1-\theta) \cdot\left(\frac{G \rho C_{p} \lambda}{d}\right)^{0.5}
\end{gathered}
$$

where $\rho$ is the density of the electrolyte $\left(2075 \mathrm{~kg} \mathrm{~m}^{-3}\right.$ for a melt with high alumina concentration $\left.{ }^{[19]}\right), C_{\mathrm{p}}$ is its specific heat capacity $\left(1883 \mathrm{~J} \mathrm{~kg}^{-1} \mathrm{~K}^{-1[1]}\right)$ and $\lambda$ is its thermal conductivity $\left(0.75 \mathrm{Wm}^{-1} \mathrm{~K}^{-1[20]}\right)$.

Experimental data concerning the fraction of the electrode surface covered by gas bubbles $(\theta)$ were compiled by Vogt and Balzer. ${ }^{[21]}$ The gas coverage increases with increasing current density, and the data could be represented by

$$
\theta=0.023 \cdot i^{0.3} \text {. }
$$

This equation was mainly based on the literature data obtained with evolution of chlorine and hydrogen at $298 \mathrm{~K}\left(25^{\circ} \mathrm{C}\right)$. For a gas that requires four electrons per molecule (oxygen) and is evolved at much higher temperature, the following modification of Eq. [21] can be suggested,

$$
\theta=0.0034 \cdot(i \cdot T)^{0.3} \text {. }
$$

According to Vogt and Balzer, ${ }^{[21]}$ the gas bubble diameter can be expected to be around $0.5 \mathrm{~mm}$.

The mass transfer coefficient for transport of alumina towards the anode as well as the heat transfer coefficient was calculated using the equations and data mentioned above, and the result is shown in Figure 3.

\section{B. Conditions at the Anode}

Using the formulas and data presented in the preceding section, the mass- and heat transfer coefficients at current density $i=10 \mathrm{kA} \mathrm{m}^{-2}$ and bubble diameter $d=0.5 \mathrm{~mm}$ become $k=5.38 \times 10^{-5} \mathrm{~ms}^{-1}$ and $h=2376 \mathrm{Wm}^{-2} \mathrm{~K}^{-1}$, respectively. The heat deficit at the anode is about $8.5 \mathrm{~kW} \mathrm{~m}^{-2}$, as discussed above. The anode can, thereby, be expected to be about $3.6 \mathrm{~K}$ colder than the surrounding electrolyte. At 95 pct current efficiency the alumina flux towards the surface becomes $0.001674 \mathrm{kgm}^{-2} \mathrm{~s}^{-1}$, and the flow of aluminum fluoride away from the anode becomes

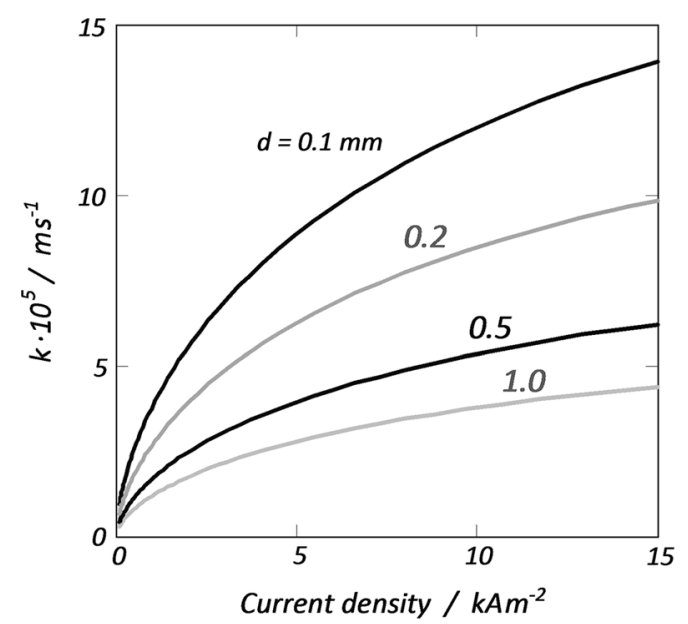

(a)

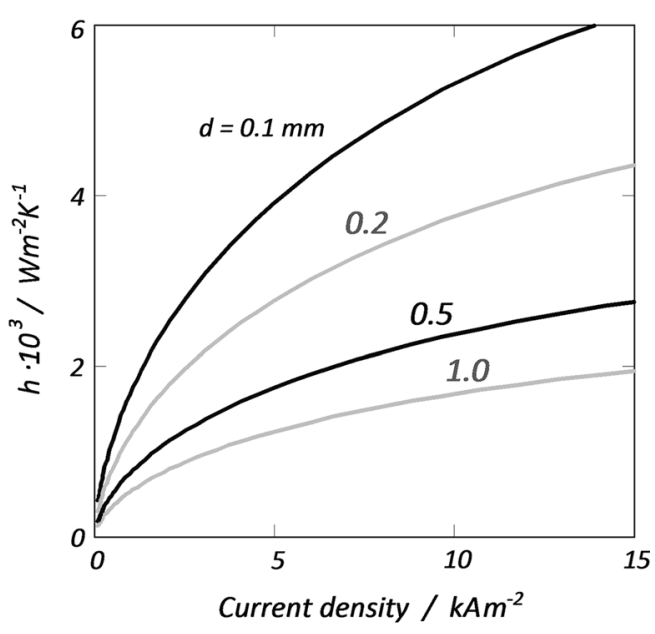

(b)

Fig. 3- (a) Mass transfer coefficient for transport of alumina towards the anode, and (b) heat transfer coefficient at the anode as functions of the current density with different bubble diameters. $T=1233 \mathrm{~K}\left(960{ }^{\circ} \mathrm{C}\right)$. 


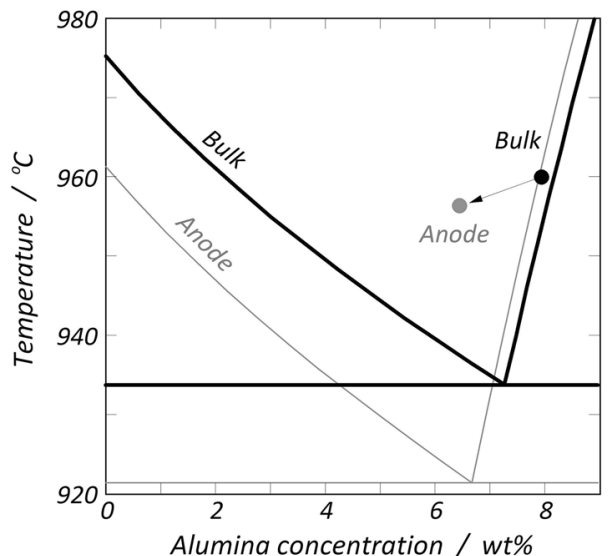

Fig. 4-Phase diagram for electrolyte containing cryolite, $12 \mathrm{wt}$ pct excess aluminum fluoride, $5 \mathrm{wt}$ pct calcium fluoride, and variable amounts of alumina. ${ }^{[22,23]}$ The electrolyte at the anode contains $1.5 \mathrm{wt}$ pct less alumina and $2.5 \mathrm{wt}$ pct more excess aluminum fluoride than the bulk, and it is $3.6 \mathrm{~K}$ colder.

$0.00276 \mathrm{kgm}^{-2} \mathrm{~s}^{-1}$ (see Eq. [6]). This gives an alumina concentration difference between the bulk and the anode of $1.5 \mathrm{wt}$ pct, while for aluminum fluoride, the difference becomes $-2.5 \mathrm{wt}$ pct provided equal mass transfer coefficients for aluminum fluoride and alumina. In sum, this means that the electrolyte close to the anode will be colder, more acid, and lower in alumina than the bulk.

The alumina concentration in a cell with inert anodes needs to be close to saturation in order to reduce corrosion of the anode material; this applies to all inert anode candidate materials. The melt composition and temperature in the bulk and at the anode are illustrated schematically in Figure 4. It appears that the change in temperature, along with the increased concentration of aluminum fluoride, helps keeping the alumina concentration closer to saturation at the anode, in spite of the reduced alumina concentration.

\section{ACKNOWLEDGMENT}

The present work was supported by the Project "Sustainable Production and Recycling of Metals" (SUPREME), financed by the Research Council of Norway and Hydro Aluminium, Boliden, Glencore, and Permascand.

\section{REFERENCES}

1. NIST-JANAF Thermochemical Tables, http://kinetics.nist.gov/janaf/.

2. V.M. Mozhaev, P.A. Polyakov, and L.M. Afanseva: Sov. J. Non Ferr. Met., 1972, vol. 13 (9), pp. 28-29.

3. V.M. Mozhaev and P.A. Polyakov: Izv. Vyssk. Uchebn. Zav, Tsvet. Met., 1980, vol. 23 (5), pp. 37-41.

4. S. Kjelstrup Ratkje: Electrochim. Acta, 1991, vol. 36 (3/4), pp. 661-65.

5. R. Ødegård, S. Julsrud, A. Solheim, and K. Thovsen: Proc. TMS-AIME, Light Met., 1991. pp. 307-13.

6. R. Ødegård, S. Julsrud, A. Solheim, and K. Thovsen: Metall. Trans. B, 1991, vol. 22B, pp. 831-37.

7. B.E. Flem, S.K. Ratkje, and Å. Sterten: Proc. TMS-AIME, Light Met., 1996, pp. 203-09.

8. S. Kjelstrup, E. Olsen, and J. Qian: Electrochim. Acta, 2001, vol. 46, pp. 1141-50.

9. A. Solheim: $11^{\text {th }}$ AustralAsian Aluminium Smelting Technol. Conf., 6-11 December 2014. Dubai, United Arab Emirates (Proc. Paper No. 13 Key3, p. 26).

10. A. Solheim and A. Sterten: Proc. TMS-AIME, Light Met., 1999. pp. 445-52.

11. K.S. Førland, T. Førland, and S.K. Ratkje: Irreversible Thermodynamics, Theory and Applications, Wiley, Chichester, 1988.

12. A. Sterten, K. Hamberg, and I. Mæland: Acta Chem. Scand., 1982, vol. A36, pp. 329-44.

13. E.W. Dewing: Metall. Trans. B, 1990, vol. 21 B, pp. 285-94. vol. 28B, pp. 1089-93.

15. K.C. Hong and O.J. Kleppa: J. Phys. Chem., 1978, vol. 82, pp. 176-82.

16. H. Kvande and W.E. Haupin: JOM, 2001, vol. 53 (5), pp. 29-33.

17. H. Vogt and K. Stephan: Electrochim. Acta, 2015, vol. 155, pp. 348-56.

18. J. Thonstad: Electrochim. Acta, 1969, vol. 14 (2), pp. 127-34.

19. A. Solheim: Alum. Trans., 2000, vol. 2 (1), pp. 161-68.

20. V.A. Khoklov, E.A. Filatov, A. Solheim, and J. Thonstad: Proc. TMS-AIME, Light Met., 1998. pp. 501-06.

21. H. Vogt and R.J. Balzer: Electrochim. Acta, 2005, vol. 50, pp. 2073-79.

22. A. Solheim, S. Rolseth, E. Skybakmoen, L. Støen, A. Sterten, and T. Støre: Metall. Trans. B, 1996, vol. 27B, pp. 739-44.

23. E. Skybakmoen, A. Solheim, and A. Sterten: Metall. Trans. B, 1997, vol. 28B, pp. 81-86. 